\title{
STRATEGIC FORESIGHT FOR SUSTAINABLE DEVELOPMENT
}

\author{
Arnoldo de Hoyos Guevaraㄹ; Ibon Zugasti Garostidi²; Rosa Alegria ${ }^{3}$
}

ABSTRACT: Moving Strategically toward the 2030 Agenda for Sustainable Development, the UN organized a Sustainable Development Solutions Network (UNSDSN) and a Platform (HLPF) in order to harness the so called Data Revolution that could help to achieve systemically the 17 Goals, by attaining local and globally the corresponding targets. For this purpose, there is a need to keep joining efforts and know-how to develop an appropriate framework and roadmap. This paper may represent a contribution based on the long-time experience of The Millennium Project (MP) dealing with the somehow related 15 Global Challenges. As matter of fact similarly to the SDG Index, the MP developed a State of The Future Index (SOFI) that has being monitoring for some time; and on this paper as an example we'll show for the case of SDG13 that deals with the critical issue of Climate Action, how the MP has being working with its related Global Challenge 1 that deals with Sustainable Development and Climate Change.

KEYWORDS: sustainable development, strategic foresight, millennium project.

RESUMO: Avançando estrategicamente em direção à Agenda 2030 para o Desenvolvimento Sustentável, a ONU organizou uma Rede de Soluções de Desenvolvimento Sustentável (UNSDSN) e uma Plataforma (HLPF) para aproveitar a chamada Revolução de Dados que poderia ajudar a alcançar sistemicamente os 17 Objetivos, alcançando globalmente os alvos correspondentes. Para este propósito, há uma necessidade de continuar unindo esforços e know-how para desenvolver uma estrutura apropriada e roteiro. Este artigo pode representar uma contribuição baseada na longa experiência do Projeto do Milênio $(P M)$, que trata dos 15 Desafios Globais de alguma forma relacionados. De fato, similarmente ao SDG Index, o MP desenvolveu um Índice do Estado do Futuro (SOFI) que está sendo monitorado há algum tempo; e neste artigo, como exemplo, mostraremos o caso do SDG13, que trata da questão crítica da Ação Climática, como o PM está trabalhando com seu Desafio Global 1, que trata do Desenvolvimento Sustentável e da Mudança Climática.

PALAVRAS-CHAVE: desenvolvimento sustentável, prospectiva estratégica, projeto do milênio.

RESUMEN: A Avanzando estratégicamente hacia la Agenda 2030 para el Desarrollo Sostenible, la ONU organizó una Red de Soluciones para el Desarrollo Sostenible (UNSDSN) y una Plataforma (HLPF) para aprovechar la llamada Revolución de Datos que podría ayudar a alcanzar sistemáticamente los 17 Objetivos, logrando objetivos locales y locales. globalmente los objetivos correspondientes. Para este propósito, es necesario seguir uniendo esfuerzos y conocimientos para desarrollar un marco y una hoja de ruta apropiados. Este documento puede representar una contribución basada en la larga experiencia del Proyecto del Milenio (MP) que se ocupa de los 15 desafíos globales relacionados de alguna manera. De hecho, de manera similar al Índice SDG, el MP desarrolló un Índice del Estado del Futuro (SOFI) que ha estado monitoreando por algún tiempo; y en este documento como ejemplo mostraremos para el caso del ODS 13 que trata el tema crítico de la Acción Climática, cómo el MP ha estado trabajando con su Desafío Global 1 relacionado con el Desarrollo Sostenible y el Cambio Climático.

PALABRAS-CLAVE: desarrollo sostenible, prospectiva estratégica, proyecto milenio. 


\section{INTRODUCTION}

Already half a century ago, Futurist Alvin Toffler publish his classical Future Schock calling our attention to the fact that civilizatory transitions were happening at an exponential rate; and moreover he added later, we were not prepared to surf the New Waves related the pos-industrial revolutions. Now with the Sustainable Development 2030 Agenda we are becoming more aware and concerned with externality impacts regarding local and global surviving conditions. So there is a great need to consider ways to foster strategic foresight that may help, not only governments, but also the private sector and civil society to get involved with collaboratively taking care of the present and future conditions regarding the five key development drivers related to the SDG: People, Planet, Prosperity, Peace and Partnership. On this paper we'll be presenting some of the alternatives going on that may contribute to the High-Level Political Forum (HLPF) that is the central platform for follow-up and review of the 2030 Agenda for Sustainable Development.

\section{FUTURE STUDIES}

There was an ancient sanctuary in Greece called Delphi, were since the earlier XIV century before Christ an Oracle could be consulted before taking important decisions, this idea gave place to the development at the Rand Corporation at the earlier 1950s of the Delphi Method to study the future by seeking a consensus among experts on a certain topic, at that time mostly military. Was already based on the development of this method that one of the founders of The Millennium Project Ted Gordon was involved. But actually different schools of future studies were being develop since that time: Some more analytic in the US called Forecasting, that extended to Foresight at the UK and another in France seeking anticipatory potential scenarios. In this sense it seems one should work with the framework of Integrated Knowledge of Charles C. Snow observing that Basic Science help us to Analyse, Social Science to Explain and Arts to Reveal. This may explain why the different cultures approach Future Studies in different although complementary ways that evolve along the time and now every day faster due to the digital revolution going on, like is the case of The United Nations ActNow Climate Campaign that is a global call to become involved on climate change. Taking advantage of technical innovation like Artificial Intelligence (AI) to foster cultural behaviour change.

\section{THE MILLENNIUM PROJECT - MP}

The Millennium Project (MP) started as United Nations University Project in the late nighties, with the purpose of seeking ways to strategically foster Global Well-Being by considering I5 Global Challenges somehow related to the I7 SDGs. The

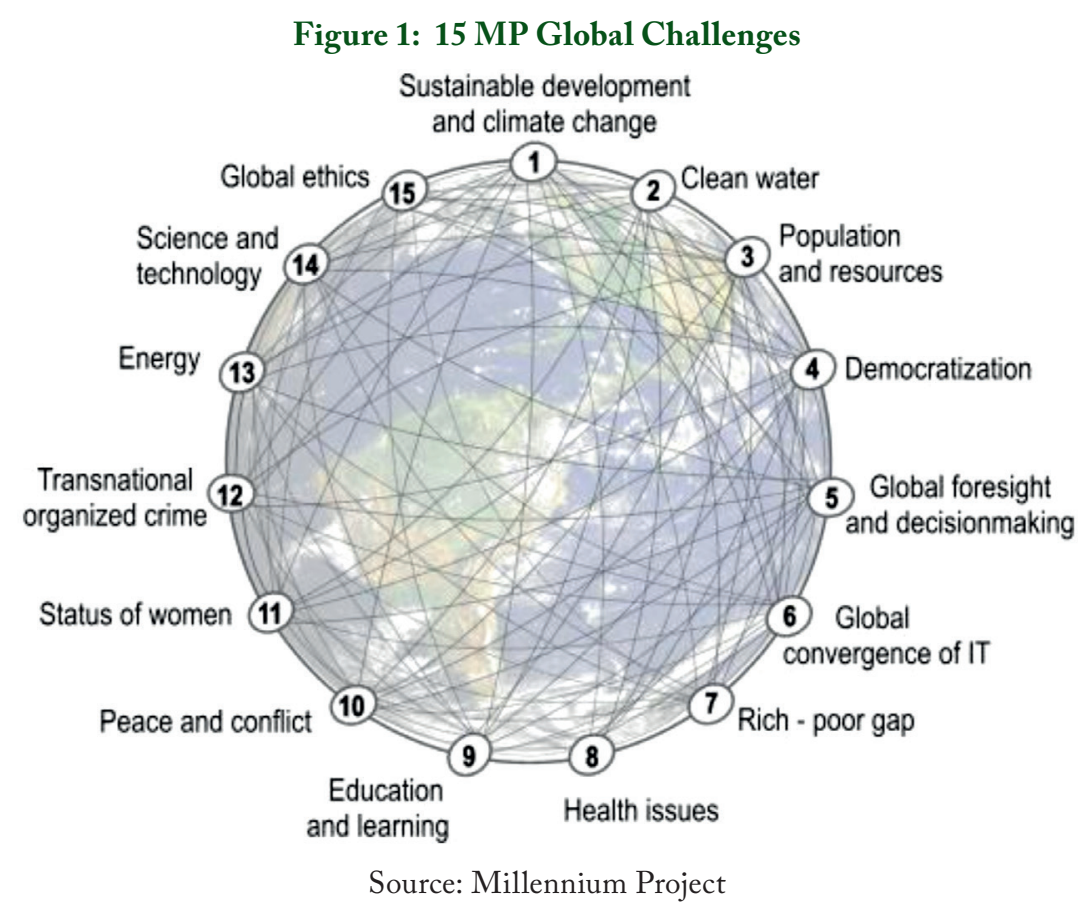


MP soon transformed into a Transinstitutional organization extending its work as a important global participatory think tank (a Collective Intelligence System), a global foresight network that now includes groups (Nodes) from more than 50 countries around the world.

Moreover every year the MP, besides considering changes and trends regarding ${ }_{5}$ Interrelated Global Challenges (Fig. I), develops with its ThinkThank network one or more foresight research's in topics related to the ${ }_{5}$ Ps ( People, Planet, Prosperity, Peace and Partnership ); the last one still going on being about The Future of Work/Technology (2050). All this information, collective Intelligence group, and software is organized into a "Global Futures Intelligence System" (GFIS), that in particular uses a Real Time Delphi(RTD), and the MP keeps publishing basic results into a very well recognized State of the Future updated reports.

3.I THE MILLENNIUM PROJECT FUTURE RESEARCH METHODS (FRM) AS A RESOURCE FOR THE SDGS DECISION-MAKING

The MP offers a Collection of more than 30 Future Research Methods (FRM), besides the most comprehensive futures studies encyclopaedic dictionary (FUTURES) that exists to date. The Millennium Project recommends that all Governments strategic systems should integrate futures research across all departments / sections and all sectors of society. Special studies like the State of the Future Report is a good resource to provide input to national strategies addressing the SDGs. Activities like early warning systems, meetings with leading experts in different topics, Real-Time Delphi, Environmental scanning, futures intelligence systems, and many other methodologies included in the more complete compilation of Foresight Methods developed by the Millennium Project that includes the studies regarding a State of The future Index (SOFI) that represent an overall view about our common future showing that generally speaking, regarding the I5 Global Challenges hopefully we'll keep slowly improving (Fig. 2), even though we still have serious socioenvironmental problems. The SOFI could also show progress regarding countries for in each of the SDG goals.

The framework for assessing the global strategic landscape and exploring national implications for policies can be a useful tool for governments to checklist the completeness of each one of the SDGs. Each UN agency could also orchestrate measurement systems for all countries to improve decision-making based on this framework. For this purpose, one could use some of the more than 30 Future Research Methodologies recommended by the MP.

Figure 2: MP State of The Future Index (SOFI)

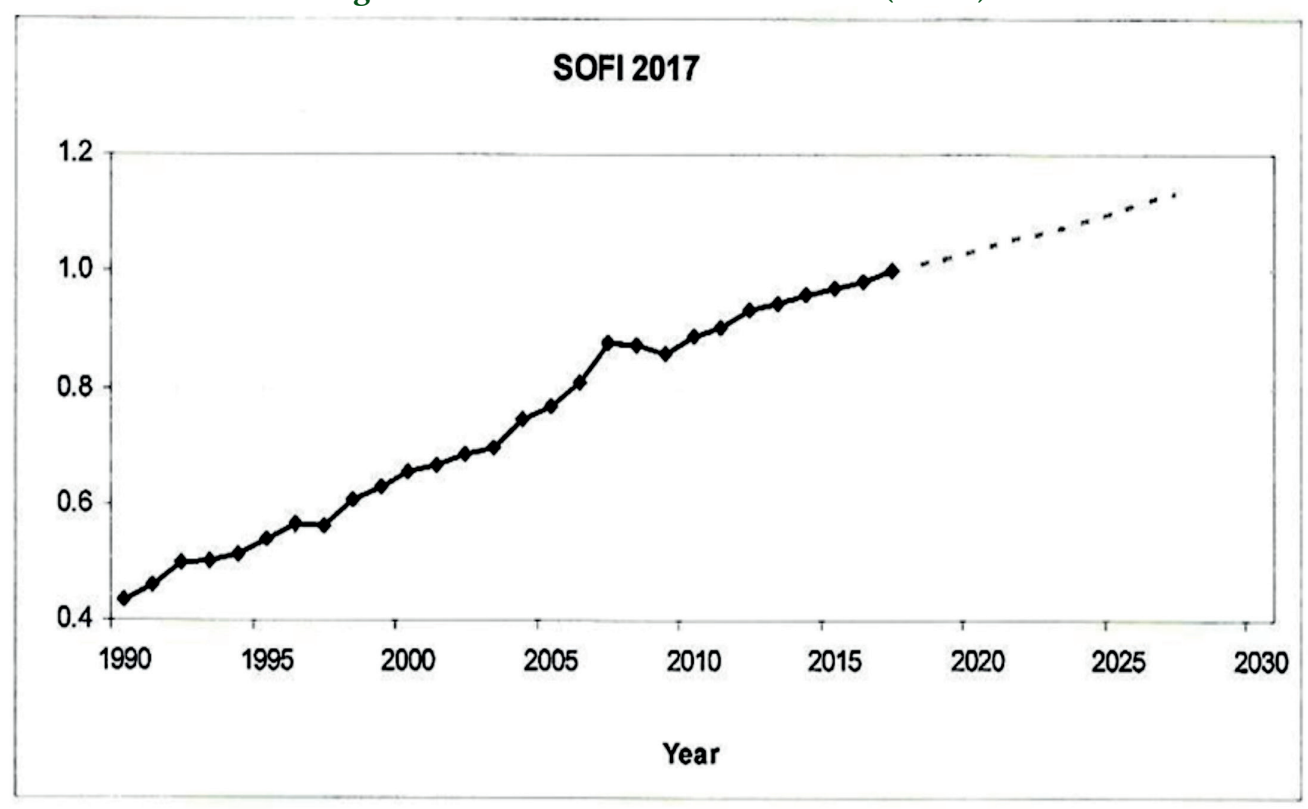

Source: Millennium Project 
3.2 DECISION-MAKING IMPROVEMENT TO FULFIL THE SDGS AND THE PROBLEM OF TIMING

We are living times of multiple crisis that require better and faster decision-making processes. The Millennium Project in its framework of $\mathrm{I}_{5}$ global challenges has used the SOFI index to measure the evolution of the world in its relation with several indicators. The result is that we are progressing more than regressing. However, that which represents regression, more concentrated on the climatic issue, exhaustion of natural resources, inequality, terrorism - are highly destructive factors that can overcome the advances, preventing humanity from advancing.

With the increasing complexity generated by the convergence of crises, the intercultural aspects of globalization and the speed of change, it has become much more difficult to make decisions.

The Millennium Project through the bi-annual study The State of the Future have concluded that we are advancing more than regressing. However, the great questions is: we will have enough time to get in the right direction?

We have no more time to make mistakes. The only choice we have is to make right decisions. That is why Ted Gordon, one of the founders of the MP, considers the Decision Making Processes (Challenge 5) as one of the two most critical Global Challenges, the other one was Global Ethics (Challenge I5).

3.3 COULD THE CAPACITY TO DECIDE BE IMPROVED AS THE NATURE OF WORK AND INSTITUTIONS CHANGE?

Through a framework containing challenges and alternative paths to solutions, the Millennium Project offers useful developments and ideas to help improve decision-making processes. IT may help respond to Challenge number 5 with the question: "How could decision making be enhanced by integrating improved global foresight during unprecedented accelerating change?

The Millennium Project tried to answer the "how's" and make institutions aware about the fragility of decision making in a long view. Leaderships are not trained to make decisions farther than 4/5 years. Governments change plans every time a new leader takes over. Business organizations are more concerned with the immediate profit than with the impacts in the future. That's why UNESCO has been working to develop an Anticipatory Culture.

Now with "artificial intelligence, big data analytics, simulations, collective intelligence systems, e-governance participatory systems, and a deeper understanding of psychological factors that impinge on decision-making and its outcomes and as mobile apps proliferate" the nature of decision-making has to change in face of the speed of change. Actually this may be happening as Governance 4.0 become effective as it may be seen in Cases like Estonia, as mentioned at the extensive UN e-Goverment Survey 2018.

Also, the nature of decision making has to change and include a deep analysis on the Impacts of developments underway. The global interdependence are not being considered by governments and organizations We are far from a global governance approach that should take into account global changes that are beyond their control. Their actions are restricted into short term and short viewed strategic planning processes.

An example of what can be a national decision making strategic is this: Finland created a permanent Parliamentary Committee on the Future in 1993 to support government foresight and decision-making; and now this also started happening in Latin-American countries like Chile, Argentina...

As a matter of fact, a long time ago Eleanora Mazzini use to say that The Governance Machine doesn't work as it should because Transformations going on happen at very different speeds: ScienceTech Transformations are extremely fast, SocioCultural Transformations take some time and Institutional Transformations are Extremely slow. So e-Goverance may help a lot with this last one, but still we'1l need a Metamorphosis, as mentioned by Edgar Morin, to deal with all.

3.4 ANTICIPATORY AND COLLECTIVE STRATEGIC INTELLIGENCE SYSTEMS: MORE RADARS LESS REARVIEW MIRRORS

Traditional planning systems are normally projections of the past as if the use of rear-view mirrors. This metaphor represents the analysis of past information, the connection with the known rather than the unknown, the preference of certainties rather than uncertainties, the attention to one only direction rather than multiple directions. This is 
not enough and does not respond to the status of the world.

The political system is being unable to produce meaningful visions for the future. Beyond the day-to-day management of the country, the political system needs to look 20, 30 years into the future and produce a vision of where the country wants to go and try to implement this vision.

Foresight planning systems can help in this. The Millennium Project frameworks may be represented as a radar that captures new information in a systemic way. The SDGs could be more easily reached if institutional radars are created so that farther future-oriented decision-making processes may be more effective. The futures-oriented information research has nothing to do with predictions or incremental trends. Forecasting and trends do not guarantee innovative ideas and disruptive innovation because they analyse the past to predict the future and relies on continuity. The landscape of analysis is now more volatile, uncertain, complex and ambiguous (VUCA) and needs disruptive answers that require anticipatory and collective intelligence systems. Actually the UN Inter-Agency and Expert Group on the SDG Indicators (IAEG-SDGs) may be moving in that direction using new dashboards, frameworks and cross matrixes approaches.

Actually the Stockholm Environmental Institute(SEI) has being working in developing a practical approach for gaining a systemic and contextual perspective on the SDGs, that may help to understand interactions, synergies and trade-offs among them and hence strategically more systemically efficient; and as they say: How the Sustainable Development Goals (SDGs) interact with each other is a key question in the implementation of the 2030 Agenda. Understanding these interactions is vital for prioritizing action and anticipating knock-on effects.

\section{THE IBEROAMERICAN FORESIGHT NETWORK - RIBER}

A few years ago ( 20I4) a group of Iberoamerican members of the MP (RIBE ) decide to join forces to try to help the Iberoamerican Region to overcome its present development hardships seeking new ways to foster Sustainable Development, something that Jorge Mattar from CEPAL was also starting doing together with Daniel Perroti form ILPES at that time; and more recently (20I6) these two organizations organized an International
Course on Strategic Foresight for dealing with the UN SDGs consisting basically in : Defining the Problem and identifying the relevant variables concerning the structural system; develop alternative scenarios; and design and build up a strategic foresight sustainable development model. Moreover actually already a year before UN SDGs were defined, the RIBER had built up and was working on this kind of model based on ${ }_{5}$ SDGs (GPS), somehow related to the I7 UN SDGs as we are going to show next; a work developed by one of our students Agris L. Dumpe Jr.

Following recommendations of the UN report: Indicators and Monitoring Framework for SDGs/ Launching a Data Revolution (2015) next we'll present some integrated Rankings.

4.I SDGS RANKING OF COUNTRIES BASED ON THE GPS THROUgh THE 5 P'S OF SUSTAINABLE DEVELOPMENT GOALS (SDGS).

The first step was to relate the RIBER ${ }_{5}$ SDGs to the I7 UN SDGs as shown in the following Table I. And also consider the relationship among the RIBER ${ }_{5}$ SDGs and the UN ${ }_{5} \mathrm{Ps}$ :

P1. PEOPLE - End poverty and hunger in all forms and ensure dignity and equality. P2. PLANET - Protect our planet's natural resources and climate for future generations. P3. PROSPERITY - Ensure prosperous and fulfilling lives in harmony with nature. P4. PEACE - Foster peaceful, just and inclusive societies

P5. PARTNERSHIP - Implement the agenda through a solid global partnership

The Next step was to relate the RIBER I5 SDGs to the ${ }_{5} \mathrm{Ps}$ as shown in Table 2.

Using these ideas it was possible, using multivariate analysis based on information (hundreds of variables for 132 countries) regarding the RIBER ${ }_{5}$ SDGs to build up a Global SD Ranking that allows in particular, to see how is The Iberoamerican Region - AIBER ( 2 I Countries) doing when compared to a group of Advanced Economy Countries - AVECO ( 27 Countries) and Other Countries - OTHER (84 Countries). The greatest difference among AVECO and the other two groups as may be seen in Fig.5 clearly being regarding Partnership and in particular Peace as it was to be expected and would need a special care. 
Figure 3: Sustainable Development 5Ps
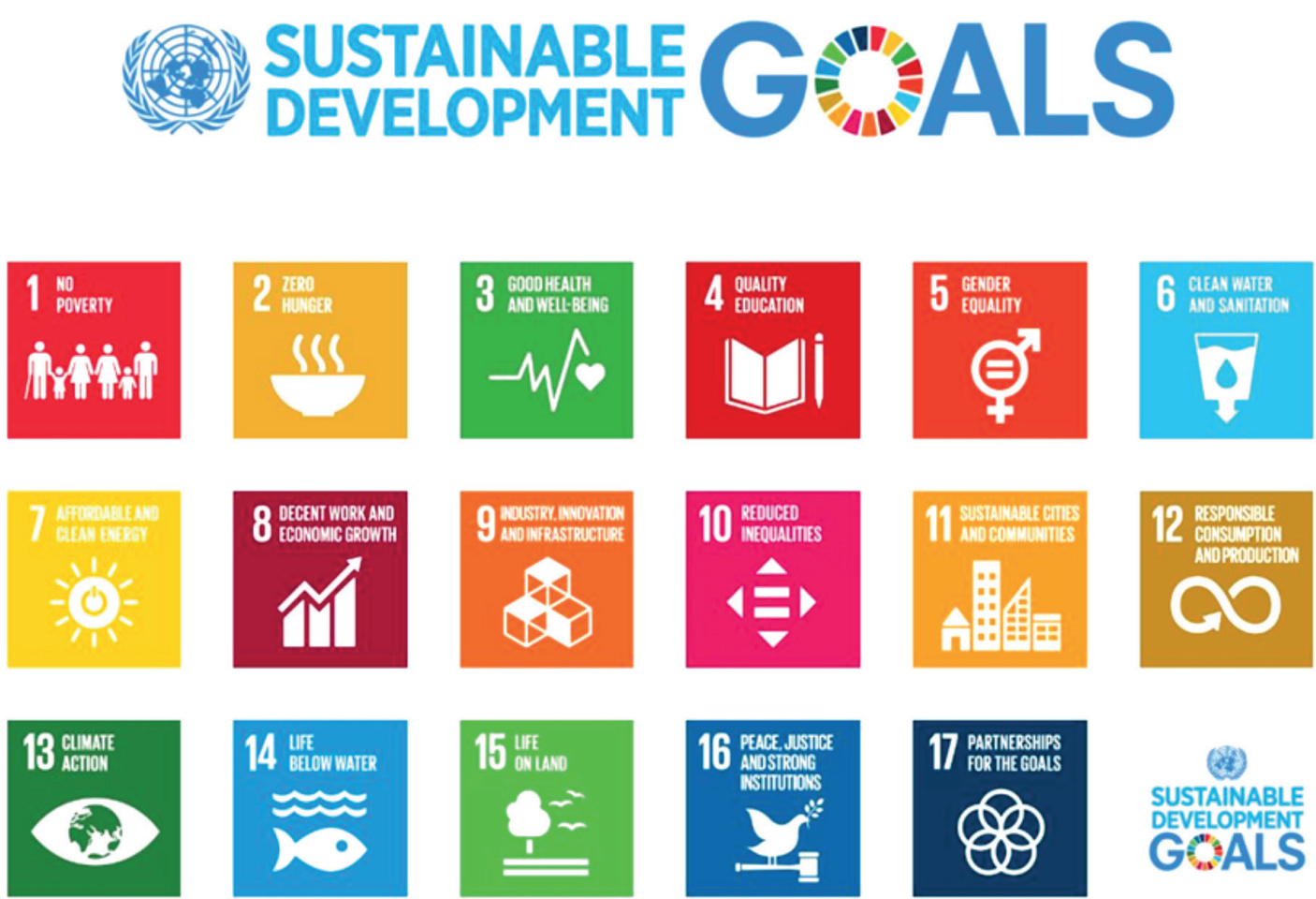

(89)

SUSTAINABLE GOALS

Source: Pinterest.com

Table.1 Relating the RIBER 15 SDGs with the UN 17 SDGs

\begin{tabular}{l|l}
$\begin{array}{l}\text { I. Basic Resources: Water, Food, Energy } \\
\text { 2. Shelter }\end{array}$ & SDG I, SDG 2, SDG 6, SDG 7, SDG I2 SDG I4 \\
3. Security and Peace & SDG I6 \\
$\begin{array}{l}\text { 4. Health and Enviroment } \\
\text { 5. Inequalities and Gender Social Inclusion }\end{array}$ & SDG 3 \\
6. The Future of Work and Education & SDG 5, SDG IO \\
7. Productive Transformaton and Sustainable & SDG 4, SDG 8 \\
Innovation & SDG 9 \\
$\begin{array}{l}\text { 8. Integration and Strategic Alliances } \\
\text { 9. Longevity Trends }\end{array}$ & SDG I7 \\
Io. Climate Change and Renewable Energies & SDG 3 \\
II. Biodiversity: Natural and Social Capital & SDG I3 \\
I2. Resilience & SDG I5 \\
I3. Democracy and Social Networks & SDG II \\
I4. Governance and Citizenship Empowerment & SDG 8, SDG I6 \\
I5. Weel-being and Quality of Life & SDG I6
\end{tabular}


Table.2 Relating the RIBER 15 SDGs to the 5Ps

RIBER I 5 SDGS

I. Basic Resources: Water, Food, Energy

2. Shelter

3. Security and Peace

4. Health and Enviroment

5. Inequalities and Gender Social Inclusion

6. The Future of Work and Education

7. Productive Transformaton and Sustainable Innovation

8. Integration and Strategic Alliances

9. Longevity Trends

Io. Climate Change and Renewable Energies

II. Biodiversity: Natural and Social Capital

I2. Resilience

13. Democracy and Social Networks

14. Governance and Citizenship Empowerment

I5. Weel-being and Quality of Life

\section{UN 5 PS}

PI, P2
PI, P2
PI, P3, P4
PI, P2, P5
PI, P2, P3, P5
PI, P3
P2, P5
PI, P5
PI
PI, P2
PI, P2, P3
PI
PI, P3
PI, P3, P4, P5
PI, P2, P3

Figure 4: Sustainable Development 5Ps

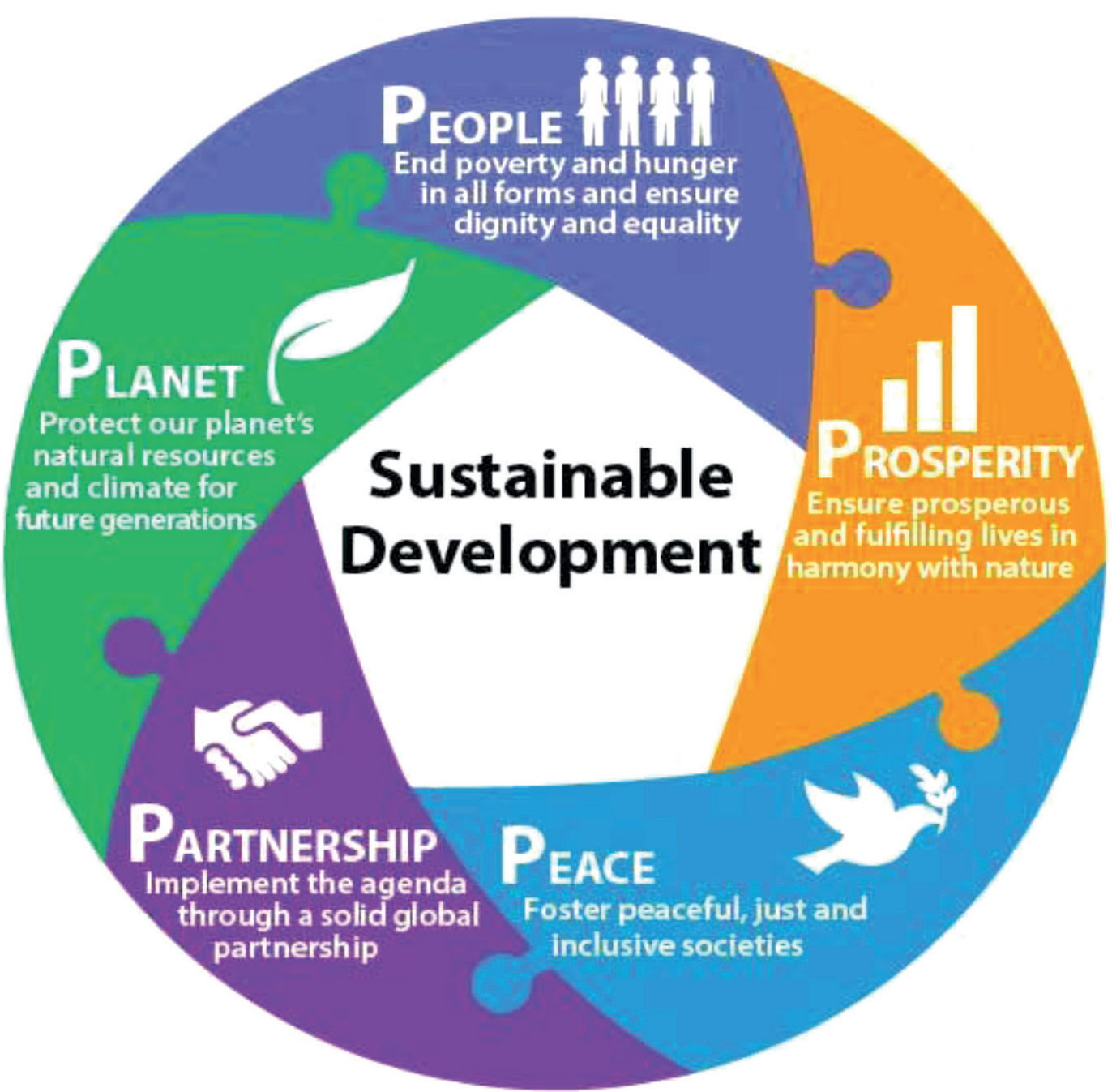

Source: Pinterest.com 


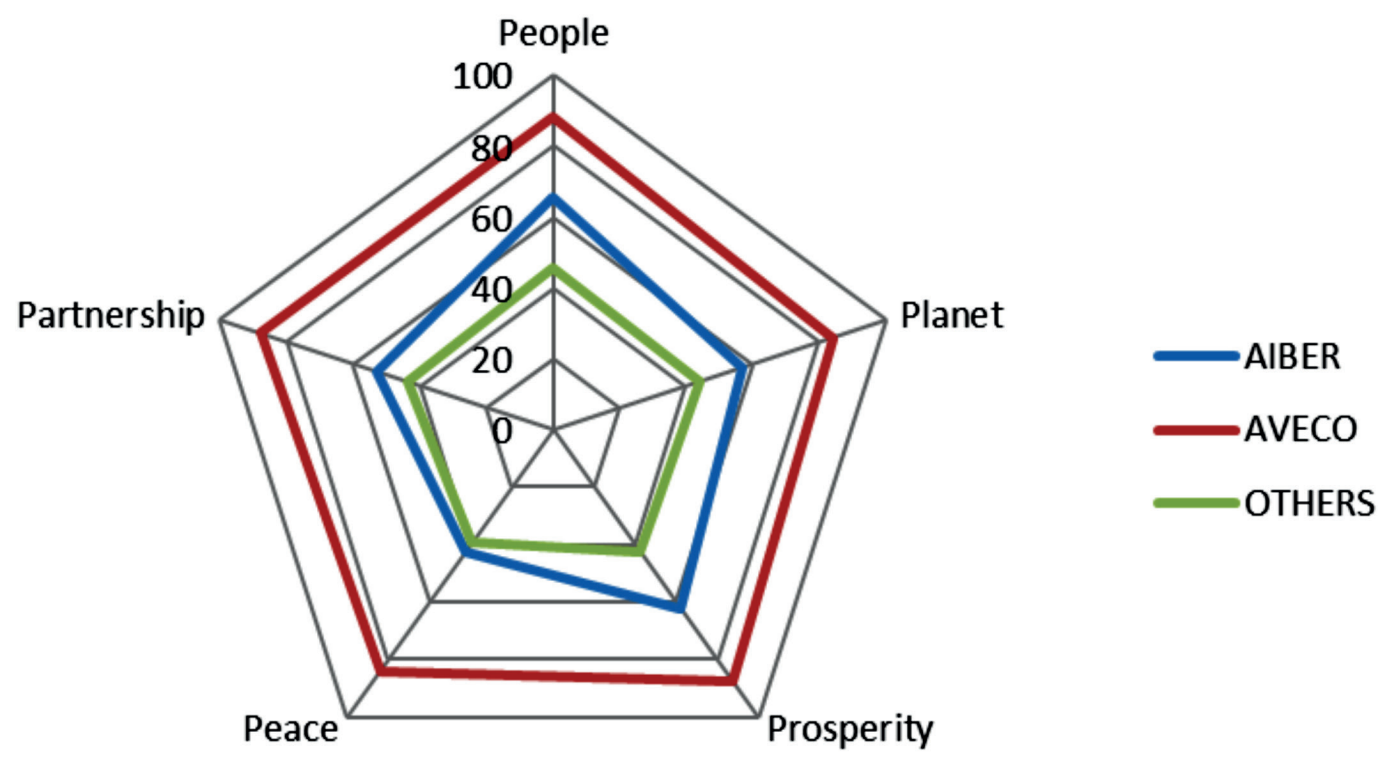

Source: NEF/PUC-SP, 2017

5. SOME MP STUDIES REGARDING SDG I3, THROUGH ITS GLOBAL CHALLENGE I (SUSTAINABLE DEVELOPMENT AND CLIMATE CHANGE)

Some 252 million years ago, global warming due to increased atmospheric $\mathrm{CO}_{2}$ that led to ocean current changes, increases in hydrogen sulphate $\left(\mathrm{H}_{2} \mathrm{~S}\right)$, and ozone depletion killed $97 \%$ of life during the Permian extinction. This could happen again unless we learn how to turn around the growing greenhouse gas emissions and reduce the volume already in the atmosphere today.I According to NASA, I6 of the I7 warmest years on record occurred since 200I, and as the UN Secretary-General recently said Climate change "is still moving much faster than we are; and the latest WEF report on Global Risks considers that over a ten-year horizon, extreme weather and climate-change policy failures are seen as the gravest threats.

The Paris Agreement on Climate Change, with 197 Parties to the Convention, that went into force in November 2016 calls for efforts to cap temperature increases to $1.5^{\circ} \mathrm{C}\left(2.7^{\circ} \mathrm{F}\right)$ above preindustrial levels. Even though the growth in $\mathrm{CO}_{2}$ emissions has slowed over the past three years due to efficiencies and a move away from coal by the U.S. and China, the accumulative effect continues warming Earth.2

According to NASA the global temperature has already increased by $0.94^{\circ} \mathrm{C}$ (I. $7^{\circ} \mathrm{F}$ ) since I880 and sea levels have risen 8-9 inches during the same period. If current trends continue, the
2017 US Climate Report projects an increase of $2.8-4.8^{\circ} \mathrm{C}\left(5-7.5^{\circ} \mathrm{F}\right)$ increase by 2 100. Sea levels are rising at 3.4 millimetres per year and ocean acidity may increase 100-150\% over pre-industrial levels by the end of this century.

Turning around GHG growth will require unprecedented global efforts since today's 7.5 billion-world population may grow another 2 billion by 2050 and the global economy is expected to triple during this same period.

Although the $\mathrm{CO}_{2}$ equivalent of $450 \mathrm{ppm}$ is the politically acceptable cap, some argue it should be 350 ppm since we already see massive impacts today with 4IO ppm, so why would 450 be sustainable? We have to reduce not only GHG emissions but also the volume of GHGs already in the atmosphere today. The Paris Convention on Climate Change and country pledges should be enforceable through boycotts, sanctions, and other means. Global citizens should understand that Earth does not possess infinite resources; that the Earth is a Closed-Loop System that should be applied to various economic, political, and environmental management systems; that consumption and waste management will have to change; and that environmental sustainability is a top economic, social value, and political priority.

World leaders have agreed to achieve i7 UN Sustainable Development Goals (Agenda 2030) for which they already developed an SDG Index and excellent interactive Dashbord. 
5.I SOME ACTIONS TO ADDRESS MP GLOBAL CHALLENGE I (SDG I3)

- U.S.-China Apollo-Like Goal, with a NASA-Like R\&D program to achieve it, that others can join; if U.S. falters, then an EU-China Goal should be pursued.

- Produce meat, milk, leather, and other animal products directly from genetic materials without growing animals: Saves energy, land, water, health costs, and greenhouse gases.

- Seawater/saltwater agriculture.

- Increase vegetarian diets.

- Retrofit older cities to Eco-Smart Cities and build new additions as Eco-smart Cities.

- Continue policies that reduce fertility rates in high population growth areas.

- Reduce energy per unit of GDP.

- Increase forest coverage.

- Transition from fossil to renewable energy sources (see http://www.go100re.net/map for current global status).

-Introduce cap-and-trade systems.

- Establish carbon taxes.

- Engage arts/media/entertainment to foster work/ lifestyle changes.

- Train community resilience teams.

- Make long-range coastal evacuation and migration plans.

- Evaluate geo-engineering options.

When working with scenarios one may work on things getting better, getting worse or keep on going the same that is business-as-usual; now the total GHG emission is about $54 \mathrm{Gt}$ of $\mathrm{CO}_{2}$ equivalent per year. In business-as-usual scenario, the emissions are estimated to reach $59 \mathrm{Gt}$ of $\mathrm{CO}_{2}$ equivalent in 2020 and $68 \mathrm{Gt}$ of $\mathrm{CO}_{2}$ equivalent in 2030. The IPCC estimates that no more than roooGt of $\mathrm{CO}_{2}$ equivalent shall be emitted between 2012 and 2100 if we want to have $66 \%$ chance of limiting the warming below $2{ }^{\circ} \mathrm{C}$. Nature's capacity to absorb human-induced emissions is diminishing. Oceans will continue absorbing human-generated $\mathrm{CO}_{2}$ for decades if not centuries, which increases acidity, affecting coral reefs and other sea life. Over the long term, increased $\mathrm{CO}_{2}$ in the atmosphere leads to a proliferation of microbes that emit hydrogen sulphide-a very poisonous gas that could lead to mass extinctions. Surface ocean $\mathrm{pH}$ has already fallen by about o.II $\mathrm{pH}$ units from preindustrial times to today, and if the current trend continues, it is likely to drop by $0.3^{-0.4}$ units by the end of this century with devastating impacts on the marine ecosystem.

If all Kyoto Protocol Annex I country pledges were fully implemented, their emissions would reach a level by 2020 that is $12-18 \%$ below the level of 1990; however, if only their unconditional pledges were implemented, the decrease would be only $5 \%$ below the 1990 level. There is also a growing fear that the target of not exceeding $45^{\circ}$ ppm of atmospheric $\mathrm{CO}_{2}$ is inadequate and should be lowered to $35^{\circ} \mathrm{ppm}$, or else the momentum of climate change could grow beyond humanity's ability to reverse it. Emissions from increased production of internationally traded products have more than offset the emissions reductions achieved under the Kyoto Protocol. Meanwhile, adaptation costs are likely to reach $\$ 300$ billion per year by

Figure 6: GHG emissions, CO2-equivalent mixing ratio (ppm)

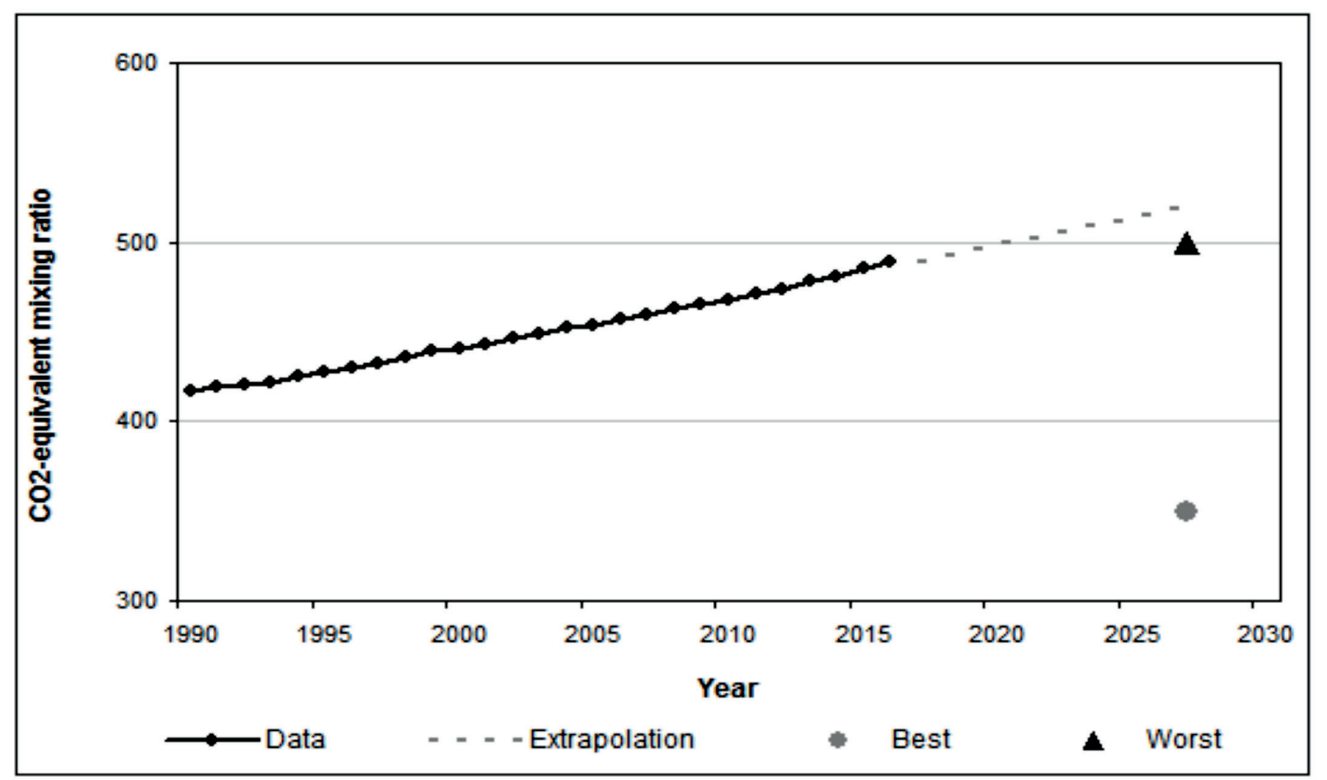


2050, even with strong emissions cuts. A study estimates that a ton of $\mathrm{CO}_{2}$ emitted causes $\$ 220$ worth of economic damage.

Global ecosystem services that provide life support and economic foundations are valued from $\$ 16$ to 64 trillion. WWF estimates that the oceans are worth at least $\$ 24$ trillion. Much of our food is dependent on bee pollination, yet few seem to realize that half of the bee colonies of the US and Europe have collapsed over the past couple of decades. Irrigated fields produce $36 \%$ of the world's food, but a fifth of the worlds' irrigated soils is affected by salt, which can cut crop yields as much as $70 \%$. About $\$ 27.3$ billion is lost each year in agricultural value due increasing salt. As ocean levels rise, seawater in will enter fresh water agricultural lands; hence, it will be wise to develop and convert to salt tolerant plants.

The size of the "global middle class" (defined as all those living in households with daily per capita incomes of between \$IO and \$IOO in PPP terms) will increase from I.8 billion in 2009 to 3.2 billion by 2020 and 4.9 billion by 2030 , drawing even more on these ecosystem services. The world spends $\mathrm{I}-2 \%$ of global GDP on subsidies that often lead to unsustainable resource use. Global waste has increased ro-fold in the last century, and it could double by 2025 from where it is today. Halving global food waste could save as much as $\$ 300$ billion a year by 2030. More than 4I million tons of e-waste were discarded in 20I4. The discarded materials including gold and silver were worth some $\$ 52$ billion, but less than $20 \%$ is estimated to have been properly recycled.

In 2014, Earth Overshoot Day - the approximate date human resource consumption exceeds nature's budget - fell on August 19, and it was already on July i on 20I8. So we'1l need I,7 Planets to support humanity demands according to the Overshootday Organization. Five countries make up nearly half of the world's ecological footprint: China, US, India, Brazil and Russia. Unless we improve our economic, environmental, and social behaviours, the next 50 years are likely to be for many disastrous conditions and extreme events. If present trends of climate change continue, one in six species on Earth could become extinct.

Poorer countries that contribute the least to GHGs are the most vulnerable to climate change's impacts because they depend on agriculture and fisheries, and they lack financial and technological resources to cope. G8 committed to the New
Alliance for Food Security and Nutrition aimed at achieving sustained and inclusive agricultural growth to raise 50 million people out of poverty over the next Io years. Annual global climate finance flows in 2013 reached $\$ 33$ r billion, $\$ 28$ billion lower than the previous year, further increasing the gap between finance needed and finance delivered. According to UNEP's Towards a Green Economy report, investing $2 \%$ of global GDP (\$I.3 trillion per year) into to key sectors can kick-start a transition toward a low-carbon, resource-efficient green economy that would increase income per capita and reduce ecological footprint by nearly $50 \%$ by 2050 compared with business as usual. As of September 20I4, more than 65 countries have green economy policies and 48 of them are taking steps to develop national green economy plans.

Climate change could be accelerated by dangerous feedbacks:

- Melting ice/snow on tundras reflect less light and absorb more heat, releasing more methane, which in turn increases global warming and melts more tundra; - Warming ocean water releases methane hydrates from the seabed to the air, warming the atmosphere and melting more ice, which further warms the water to release more methane hydrates;

- The use of methane hydrates or otherwise disturbing deeper seabed's releases more methane to the atmosphere and accelerates global warming;

- Melting ice in Polar Regions reflect less light, absorbs more heat, which further increases melting.

Glaciers are melting, disease patterns are changing, and coral reefs are dying at an accelerating rate. The Gulf Stream system has weakened to its lowest level in I,IOo years, possibly due to an influx of freshwater from Greenland's melting ice sheet. A third (FAO) to a half (WFF) the world's topsoil is destroyed and could run out in 60 years. Some $30 \%$ of fish stocks have already collapsed, and $2 \mathrm{I} \%$ of mammal species and $70 \%$ of plants are under threat. Oceans absorb 30 million tons of $\mathrm{CO}_{2}$ each day, increasing their acidity. The number of dead zones in the oceans-areas with too little oxygen to support life-caused by agricultural runoffs, has doubled every decade since the ig6os.

Because the U.S. and China are the largest GHG polluters and have the largest economies, they have the moral responsibility to lead the world in adapting to and turning around climate change. US-China November 2014 joint 
announcement pledged GHG emissions caps, collaboration on cleaner energy research, carbon capture and reuse, eco-smart city designs, and phasing down of their use of Hydrofluorocarbons, but they have not yet declared a joint bold Apollolike goal - such as reducing atmospheric $\mathrm{CO}_{2}$ to $350 \mathrm{ppm}$ - with a NASA-like R\&D strategy that could rally global collaboration. Such a U.S.China lead strategy might focus on new technologies like electric cars, saltwater agriculture, carbon capture and reuse, solar power satellites, maglev trains, urban systems ecology, pure meat without growing animals (produced from either stem cells or vegetable inputs), and a global climate change collective intelligence system to support better decisions and keep track of it all. It is estimated that growing pure meat without growing animals would generate $96 \%$ lower GHG emissions, use $45 \%$ less energy, reduce land use by $99 \%$, and cut water use by $96 \%$ compared with growing animals for meat. These technologies need to be complemented by policies that support carbon taxes, cap and trade schemes, reduced deforestation, industrial efficiencies, co-generation, conservation, recycling, and switch of government subsidies from fossil fuels to renewable energy. (Pakistan and Venezuela are spending twice as much on fossil fuel subsidies as they are on public health.) Successful technological and policy implementation in many less developed countries will need assistance.

Seriously, addressing global warming will require better conservation, higher efficiencies, changes in food and energy production, methods to reduce the GHGs that are already in the atmosphere, and adapting to climate changes already in motion for many years to come.

Scientists are studying how to build towers to suck $\mathrm{CO}_{2}$ from the air, sequester $\mathrm{CO}_{2}$ underground, spread iron powder in oceans to increase phytoplankton to sequester $\mathrm{CO}_{2}$, genetically alter coral to better absorb $\mathrm{CO}_{2}$, reduce solar input with large scale geoengineering project like sunshades in orbit, and reuse carbon at power plants to produce cement and grow algae for biofuels. Large-scale geoengineering, such as spraying sulphate aerosols into the atmosphere to reflect some sunlight, may have problems with stratospheric ozone depletion, reaching international agreements to do it, and make the daytime sky significantly brighter and whiter. Other suggestions include retrofitting coal plants to burn leaner and to capture and reuse carbon emissions, raising fuel efficiency standards, and increasing vegetarianism, (FAO reports that the livestock sector emits more GHGs than transportation does). Others have suggested new taxes, such as on carbon, international financial transactions, urban congestion, international travel, and environmental footprints. Such taxes could support international public/private funding mechanisms for high-impact technologies. Massive public educational efforts by professional networks (from scholarly associations to Rotary Cubs) should use social media, popular film, television, music, games, and contests to stress what we can do to better pressure political and other leaders.

Without a global strategy to address climate change, the environmental movement may turn on the fossil fuel and livestock industries. The legal foundations are being laid to sue for damages caused by GHGs. Climate change adaptation and mitigation policies should be integrated into an overall sustainable development strategy. Without sustainable growth, billions more people will be condemned to poverty, and much of civilization could collapse, which is unnecessary since we know enough already to tackle climate change while increasing economic growth. Unfortunately, we do not have sufficient acceptance of universal ethical principles for successful implementation. MP Global Challenge I and hence SDG I3 will be addressed seriously when green GDP increases while poverty and global GHG emissions decrease for five years in a row.

\subsection{SOME REGIONAL CONSIDERATIONS}

Africa: Among ten countries estimated to become the most affected by climate change are in Africa: Sierra Leone, South Sudan, Nigeria, Chad, Ethiopia, the Central African Republic, and Eritrea. Since Africa contributes little to GHGs, its focus should be more on adaptation to climate change than on mitigation. It is getting about $\$ \mathrm{I}^{-2}$ billion per year now for adaptation, but needs $\$ 7-\mathrm{I} 5$ billion per year for adaptation by 2020 , and $\$ 50$ billion per year by 2050 . Financial flows for adaptation, however, only amounts to $\$ \mathrm{I}-2$ billion a year today. Introduction of drought resistant seeds, eco-friendlier farming, closed environmental agriculture, seawater farming along the coasts, reforestation, and reduction of slash and burn agricultural practices, will be needed to avoid the IPCC forecast that climate change could reduce 
rain-feed Sub-Saharan agriculture by $50 \%$ by 2020 . Price and weather-indexed insurance schemes will help Africa stabilize prices in domestic markets and help farmers adapt to climate change. If agricultural practices do not change and global warming exceeds $3^{\circ} \mathrm{C}$, virtually all of the present maize, millet, and sorghum cropping areas across Africa could become unviable.

Solar energy in the Sahara is strategic for African sustainable growth. Africa needs about $\$ 675$ billion by 2030 to achieve low-carbon sustainable growth; the current carbon market for mitigation is not sufficient to address this. The Clean Development Mechanism, the Reducing Emissions from Deforestation and Forest Degradation program, and the voluntary offset program are not fully utilized. Africa's total ecological footprint is set to double by 2040 . Ethiopia is implementing its climate-resilient green economy plan to become carbon neutral by 2030. Mayors in Mali are now required to have couples plant trees as part of their marriage registration process. Ten African nations have pledged to include the economic value of natural resources in their national accounts. Meanwhile, West Africa is losing \$1.3 billion a year due to illegal and unregulated fishing, and criminal groups take up to I.3 billion worth of natural resources such as gold, timber and ivory from DRC every year. Militia and terrorist groups in and around Africa may earn up to $\$ 289$ million annually from illegal or unregulated charcoal trade.

Asia and Oceania: China, the largest GHG polluter in the world, plans to begin to reverse the amount of its GHG emissions by 2030, and have $20 \%$ of its energy from zero emissions sources by that year. The region has half of the world's megacities and the majority of the world's poverty, many of which live in densely populated slums vulnerable to climate change. Rapid applications of urban systems ecology will be vital for sustainable development of the region. India loses $\$ 80$ billion per year, or nearly $6 \%$ of its GDP due to environmental degradation, and more than half the damage is attributable to air pollution. Particulate matter pollution reduces life expectancy by 3.2 years for 660 million Indians in polluted urban cities. Meanwhile, lung cancer has doubled in Beijing over the last decade and pollution increasingly becomes a cause of protests and lawsuits. Chinese government banned the anti-air pollution documentary "Under the Dome" after it attracted
200 million viewers within a week. China's solid waste will grow from about 573,000 tons a day in 2005 to $\mathrm{I} .5$ million tons in 2025 . It has pilot emissions trading systems (ETS) in seven provinces and cities and launched national ETS in 2016. $\mathrm{US}_{\$ 320}$ billion worth of investment will be needed annually to meet China's environmental targets. The effects of deforestation in south and South East Asian climate needs to be better understood. Due to the effects of global warming, the 103,000 citizens of Kiribati are expected to become refugees; and hence, the government has bought 6,000 acres of land in Fiji for a reported $\$ 9.6$ million to resettle this population. Bangladesh will need new agriculture to save farming from ocean level increases of salt-water incursions and housing adaptations. Australia repealed the Carbon Tax, which was introduced in 20I2, but WWF says it could achieve net zero emission by 2050 at a cost of $0.2 \%$ of GDP.

Europe: EU is on track to achieve its 2020 climate/energy objectives (GHG emissions 20\% lower than $1990 ; 20 \%$ of energy from renewables; $20 \%$ increase in energy efficiency). EC adopted a low-carbon roadmap that would cut emissions by $80-95 \%$ by 2050 . The EU-28 committed in 2014 to the 2030 framework policy to reduce GHG emissions by $40 \%$ from 1990 levels by 2030 , and increase both energy efficiency and share of renewable energy by $27 \%$ from 1990 levels. Member States will have flexibility to set national objectives and policies. The sectors covered by EU ETS have already reduced their emissions by $\mathrm{I} 3 \%$ from 2005 to 2013 , but incentives for low-carbon investments are too low today due to excess of allowance and sluggish economy. The EU carbon price is around $€ 7$ euros per tonne in mid-2015, down from its peak of over $€ 30$ and now again had risen to an intraday peak of 26.89 euros (\$30.22) a tonne as of 1349 GMT, its highest since July 2008, due to reforms to strengthen the EU ETS introduced in 2018. Already in 20I3, fiscal revenues from auctioning allowances in the EU ETS amounted to EUR €3.6 billion (of which, around $€ 3$ billion will be used for climate and energy related purposes).

Germany plans to close 84 coal plants by 2038 . France introduced a carbon tax for supporting the transition towards renewables and promoting energy efficiency. Spain's total greenhouse gas emissions fell by $20 \%$ to 344 million tonnes in 2012 from 432 million tonnes in 2007; however, subsidy cuts for renewable energy could change 
this picture. In fact, Greenhouse gas emissions in Spain must be cut by one third in just over a decade if the country is to meet its 2030 goals. Russia aims to reduce GHG emissions by $22-25 \%$ by 2020 compared to 1990 (which is still an increase in absolute terms, since Russia's emissions plunged sharply after the collapse of the Soviet Union). Nitrogen pollution from farms, vehicles, industry, and waste treatment costs the EU up to $€ 320$ billion per year. The EC is preparing a circular economy strategy to increase resource-efficiency by $30 \%$ by 2030 which is expected to boost GDP by nearly $\mathrm{I} \%$ and create 2 million additional jobs. Air pollution in Europe cost \$1.6 trillion, or nearly one-tenth of the EU's GDP, in premature deaths and diseases. At the end of EU's 'Year of Air', the EU proposed a new strategy toward 2030, which would avoid 58,000 premature deaths and save as much as €I40 billion per year. The UK plans to have its own "GDP-plus" national accounts by 2020 . Russia has the world's second largest total bio capacity reserve and is the only major economy not facing a growing dependence on other nations' ecosystems. Between 1992-2009 its reserve has further improved from 0.9 to $2.6 \mathrm{GHA}$ (global hector area a measure of bio capacity) per capita. Norwegians generated the greatest volume of e-waste in per-capita basis $(28 \mathrm{~kg})$, followed by Switzerland, Iceland, Denmark and UK.

Latin America: The region faces a $\$ 100$ billion annual loss by 2050 if the global temperature rises $2^{\circ} \mathrm{C}$ over pre-industrial levels. Mexico and Colombia are implementing sector-wide crediting mechanisms that reward low emission activities. Chile approved a carbon tax to start in 20I8. South America has $40 \%$ of the planet's biodiversity and about half of the world's carbon stored in tropical forests. Brazil has the world's largest total bio capacity reserve (about 9.6 GHA per capita), but unless more environmentally-friendly policies are successful, it could cross into deficit within the next 50 years. Deforestation rate in Brazil went down for several years, but the annual deforestation rates increased $28 \%$ for the period August 20I2-July 20I3, and now has going up again with the new government. The demand for hydropower and biofuels may reduce Latin America's forests as a carbon sink. The dieback of the southern part of the Amazon rainforest is expected to be greater than expected because the forest is drying faster than the IPCC models assumed. $40 \%$ of Brazilian businesses reported emission reduction targets a few years ago. Recycling in Brazil generates $\$ 2$ billion a year while avoiding ro million tons of GHG emissions. According to IICA, Latin America holds 43\% of the world's potential for agricultural growth. It is rapidly expanding this potential while trying not to damage vital ecosystem services. Mexico's new climate change law sets legally binding emission reduction goals: $30 \%$ below business-as-usual levels by 2020 , and by $50 \%$ below 2000 levels by 2050. In Peru, more than $50 \%$ of forest cover on the coast was already lost, and more than 150,000 hectares of forest are lost annually by agriculture and mining.

North America: US $\mathrm{CO}_{2}$ emissions fell $3 \%$ during 20I6. It pledged to cut GHS emissions by $26-28 \%$ by 2025 from 005 levels. But now after years of decline, US carbon emissions are rising again due to Trump's Government. Methane production in the US could be $50 \%$ or more than previous EPA estimates due to fossil fuel production and livestock industries, not previously considered. Cities and states initiate and implement more policies for sustainable development and reducing GHGs than the federal government. California and Québec linked their carbon markets in 20I4; with the inclusion of the transport sector in January 20I5, their linked ETS is the world's third largest U.S. Oil companies are beginning to plan for carbon taxes. Bank of America announced its Io-year, $\$ 50-$ billion green investment program.

A U.S. National Academy of Sciences panel called for better government coordination to implement an abrupt [years to decades faster than expected] climate change early warning system, while the U.S. Congress refused to end oil subsidies. Honey bee keepers have reported that bee population has been falling about 30\% per year since 2006. Air pollution and exposure to toxic chemicals cost U.S. children $\$ 76.6$ billion in health expenses. The U.S. will invest $\$ 880$ million to clean up Florida Everglades. Permafrost temperature in northern Alaska increased about $4^{-} 7^{\circ} \mathrm{C}$ during the last century, almost half of it during the last 20 years. Boy Scouts of America created Sustainability Merit Badge.

Canada's tar sends exploitation continue to raise environmental concerns. The Alberta government introduced legislation to create a new environmental monitoring agency focused on the oil sands. The new Alberta government promises new climate change strategy. Canada's intended nationally determined contribution is committing 
Canada to reduce GHG emissions by $30 \%$ below the 2005 levels by 2030. Ontario committed to reduce its GHG emissions by $37 \%$ below 1990 levels by 2030, while British Columbia's carbon tax system is one of the most significant in the Western Hemisphere.

\section{CONCLUSION}

The MP experience dealing for decades with Strategic Foresight regarding I5 Global Challenges closely related to the i7 SDGs may provide through his think-tank experience important contributions to foster the UN Agenda 2030.

For the UN Climate Action Summit 2019 that will take place in New York on September 23, UN Secretary Antonio Guterres is pressing the countries representatives for realistic plans to reduce greenhouse gas emissions by $45 \%$ over the next decade, by means of full transformation of economies in line with sustainable development goal since. uneven growth, rising debt levels, possible upticks in financial volatility, and heightened global trade tensions are hampering progress on reaching the Sustainable Development Goals (SDGs). This is reinforced by the Energy Transition Commission (ETC) very recent report Mission Possible declaring that full decarbonisation is technically feasible with technologies that already exist and could cost less than $0.5 \%$ of Global GDP, but it could take longer due to uneven growth. So there is still some questions like to what extent will the poor countries benefits form the $\mathrm{COP}_{24}$ (IIED)?

The question is if the present geopolitical deglobalizing crisis that is going on, as well as the present impacts on local unstable governments will allow to actually develop and implement Strategic Foresight Planning focusing Sustainable Development, before is too late. This means changing Mind Sets of present day Governance, and perhaps moving into what it is now called Society 5.0, an idea that came from Japan that helps to develop human strengths and values as mentioned by Seiichi Matsuo, President of Nagoya University. For this purpose, the project Education for The Future (Teach the Future) develop by the Futurist Peter Bishop may be of some help.

\section{REFERENCES}

Alegria, R. (2019). Teach The Future. Brazil. Access: June 2 2019. Avaliable in: https://futuroexponencial.com/author/ rosa-alegria/

(2015). Prospectiva Estratégica e Visão de Futuro, NEF/PUC-SP. Access: June 2 2019. Avaliable in:

https://www.pucsp.br/sites/default/files/download/ prospectiva_estrategica_e_visao_de_futuro_-rosa_alegria.pdf Barakat, S, Endalew, E. J. (2019). LDCs, negotiations and the climate crisis: Will the poorest countries benefit from the COP24 climate package? IIED. Visto em 02jun19. Disponível em: https://pubs.iied.org/10200IIED/

Barket, K. (2017). Lessons from Latin America on implementing the 2030 Agenda: learning from a regional retretat. Independent Research Forum IRF. Access: June 2 2019. Avaliable in: https://www.sei.org/publications/lessonslatin-america-implementing-2030-agenda

Chestney, N. (2019). CORRECTED-UPDATE 2-EU carbon price hits over 10-year high on BREXIT extension hopes Reuters. Access: June 2 2019. Avaliable in:

https://uk.reuters.com/article/eu-carbon-prices/update-2-eucarbon-price-hits-over-10-year-high-on-brexit-extensionhopes-idUKL8N21S30X

ESS-DIVE Environmental Systems Science Data Infrastructure for a Virtual Ecosystem.: Access: June 22019. Avaliable in: https://ess-dive.lbl.gov/

ETC Mission Possible: Reaching net-zero carbon emissions from harder-to-abate sectors by mid-century. Access: June 2 2019. Avaliable inhttp:/www.energy-transitions.org/sites/ default/files/Global PressRelease-MissionPossible.pdf

Global Footprint Network. Access: June 2 2019. Avaliable in:https://www.footprintnetwork.org/

Guterres, A. (2019). Critical moment for Sustainable Development. UN Forum on Financial and Development. Access: June 2 2019. Avaliable in: https://news.un.org/en/ story/2019/04/1036681

(2018). Climate change is still moving much faster than we are. UN Headquarters on Climate Change. Access: June 2 2019. Avaliable in: https://news.un.org/en/ story/2018/03/1006271

Haryama, Y. (2017). Society 5.0: Aiming for a New Humancentered Society. Hitachi. Access: June 2 2019. Avaliable in:: https://www.hitachi.com/rev/archive/2017/r2017_06/trends/ index.html

Heath, N. (2019). How Estonia became an E-Government Powerhouse, TechRepublic. Access: June 2 2019. Avaliable in: https:/www.techrepublic.com/article/how-estonia-became-ane-government-powerhouse/

HLPF UN High-Level Political Forum on Sustainable Development. Access: June 2 2019. Avaliable in: https:// sustainabledevelopment.un.org/hlpf/20191

Keidaren (2016). Toward realization of the new economy and societ. Access: June 2 2019. Avaliable in: http://www. keidanren.or.jp/en/policy/2016/029_outline.pdf

Matsuo, S. (2018). The educational philosophy of a Nobel Prize factory. President of Nagoya University interview. Access: June 2 2019. Avaliable in: https://www.globaljapan.world/leader/ nagoya-university/seiichi-matsuo/ 
Miller, R. (2018). Transforming The Future. Anticipation in the 21st Century, Taylor Francis. Access: June 22019. Avaliable in: https://www.taylorfrancis.com/books/e/9781351048002

MP GFIS Global Futures Intelligence System. Access: June 2 2019. Avaliable in:http://www.millennium-project.org/ projects/global-futures-intelligence-system/

. State of The Future. Access: June 2 2019. Avaliable

in:http://www.millennium-project.org/publications-2-3/

15 Global Challenges.: Access: June 22019.

Avaliable in: http://www.millennium-project.org/projects/ challenges/

FRM Futures Research Methodology Version 3.0.: Access: June 2 2019. Avaliable in: http://107.22.164.43/ millennium/FRM-V3.html

Morin, E. (2011). La Voie : Pour l'avenir de l'humanité, Fayard, 2011

Nakanishi, H. (2018). How Japanese businesses are preparing for a super smart society ( Society 5.0). Global Japan. Access: June 2 2019. Avaliable in:

https://www.globaljapan.world/article/how-japanesebusinesses-are-preparing-for-a-super-smart-society/

Noaa Earth System Research Laboratory. Access: June 2019. Avaliable in: https://www.esrl.noaa.gov/

Sachs, J. et al. (2018). SDG Index and Dashboards Report. New York: Bertelsmann Stiftung and Sustainable Development Solutions Network (SDSN).: Access: June 2 2019. Avaliable in: https://dashboards.sdgindex.org/\#/

Stoknes, P. E. (2015). What we think when we try not to think on Global warming. Chelsea Green Publ.

THUMBERG, G. (2018). The disarming case to act right now on climate change TED Talk. Access: June 2 2019. Avaliable in: https://www.ted.com/speakers/greta_thunberg

UN Climate Change Take Climate Action. Access: June 2 2019. Avaliable in: https://www.un.org/en/climatechange/ take-action.shtml

UN E-Goverment Survey (2018). Gearing E-Government to support transformation towards Sustainable and Resilient Societies. MILLER, R. TRANSFORMING THE FUTURE. Anticipation in the 21st Century, Taylor Francis. Access: June 2 2019. Avaliable in: https://www.taylorfrancis. com/books/e/9781351048002, https://publicadministration. un.org/egovkb/Portals/egovkb/Documents/un/2018Survey/E-Government\%20Survey\%202018_FINAL\%20 for\%20web.pdf

UNSDN Indicators and Monitoring Framework for SDGs/ Launching a Data Revolution, (2015). Access: June 22019. Avaliable in:http://unsdsn.org/wp-content/uploads/2015/05/ FINAL-SDSN-Indicator-Report-WEB.pdf, https:// unstats.un.org/sdgs/indicators/Globa1\%20Indicator\%20 Framework\%20after\%20refinement_Eng.pdf

WEF (2019). The Global Risks Report. Access: June 2019. Avaliable in: https://www.weforum.org/reports/the-globalrisks-report-2019

Weitz, N. et al. (2017). Towards systemic and contextual priority setting for implementing the 2030 Agenda. Sustainability Science, 2017. Access: June 2 2019. Avaliable in: https://www.sei.org/publications/systemic-contextualpriority-setting-2030-agenda/
(2019). Disentangling interactions between the SDGs, SEI. Access: June 2 2019. Avaliable in: https://www. sei.org/projects-and-tools/projects/disentangling-interactionssustainable-development-goals/ 